Jurnal Tanah dan Sumberdaya Lahan Vol 7 No 2 : 209-214, 2020

e-ISSN:2549-9793, doi: 10.21776/ub.jts1.2020.007.2.04

\title{
PENGARUH BERBAGAI JENIS KAPUR DALAM APLIKASI PENGAPURAN UNTUK MEMPERBAIKI SIFAT KIMIA ULTISOL
}

\author{
Effect of Various Types of Lime in Liming Application to Improve \\ Chemical Properties of Ultisols
}

\author{
Amsar Maulana*, Herviyanti, Teguh Budi Prasetyo \\ Program Studi Ilmu Tanah, Fakultas Pertanian, Universitas Andalas, Padang, Sumatera Barat 25163 \\ *Penulis korespondensi: amaulana.1005@gmail.com
}

\begin{abstract}
Liming increases soil fertility through improved soil conditions in acidic soils (Ultisols). This study aimed to determine the effect of limes $\left[\mathrm{CaO} ; \mathrm{Ca}(\mathrm{OH})_{2} ; \mathrm{CaCO}_{3}\right.$ and $\left.\mathrm{CaMg}\left(\mathrm{CO}_{3}\right)_{2}\right]$ on the chemical properties of Ultisols of Limau Manis Padang. Treatments tested in this study application of four types of lime, i.e. $\mathrm{A}=\mathrm{CaO} ; \mathrm{B}=\mathrm{Ca}(\mathrm{OH})_{2} ; \mathrm{C}=\mathrm{CaCO}_{3}$; dan $\mathrm{D}=\mathrm{CaMg}\left(\mathrm{CO}_{3}\right)_{2}$. On an Ultisol. $\mathrm{A}$ control treatment with no application of lime was also included in this study. After incubation of the soil-lime mixtures for two weeks, the results of the study showed that liming using dolomite $\left[\mathrm{CaMg}\left(\mathrm{CO}_{3}\right)_{2}\right]$ was more effective in improving the chemical properties of Ultisols, compared to other types of lime $\left[\mathrm{CaO} ; \mathrm{Ca}(\mathrm{OH})_{2} ; \mathrm{CaCO}_{3}\right]$. The effect of dolomite on 1 *exchangeable $\mathrm{Al}(1 \mathrm{me}$ Ca $\left.100 \mathrm{~g}^{-1}\right)$ improved chemical properties of an Ultisol from Limau Manis Padang such as $\mathrm{pH} \mathrm{H}_{2} \mathrm{O}$ by 0.35 unit, available $\mathrm{P}$ by $1.03 \mathrm{ppm}$, exchangeable $\mathrm{Al}$ by $0.91 \mathrm{cmol}_{\mathrm{c}} \mathrm{kg}^{-1}$; exchangeable $\mathrm{H}$ by 0.92 $\mathrm{cmol}_{\mathrm{c}} \mathrm{kg}^{-1}$; CEC by10.49 $\mathrm{cmol}_{\mathrm{c}} \mathrm{kg}^{-1}$; exchangeable $\mathrm{K}$ by $0.03 \mathrm{cmol}_{\mathrm{c}} \mathrm{kg}^{-1}$; exchangeable Ca by 0.44

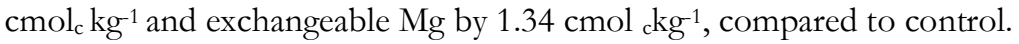

Keywords: acidic soil, chemical properties, lime, Ultisol

\section{Pendahuluan}

Keasaman tanah merupakan masalah global dalam produksi pangan untuk populasi manusia yang semakin bertumbuh dan ketersediaan tanah marjinal atau tanah masam yang berlimpah seperti Ultisol. Sekitar 30\% tanah di dunia berada di bawah pengaruh pengasaman (Shaaban et al., (2015). Ultisol adalah salah satu jenis tanah yang ada di Indonesia yang tersebar di beberapa pulau besar yang mencapai wilayah sekitar 45.794 .000 ha dengan $25 \%$ dari total luas daratan Indonesia. Lahan ini berkembang pada berbagai topografi, dari bergelombang hingga bergunung-gunung dengan curah hujan yang tinggi (Alibasyah, 2016). Di Sumatera Barat, Ultisol tersebar luas di berbagai daerah, salah satunya di Kota Padang, seperti tanah di Kebun Percobaan Fakultas Pertanian, Limau
Manis Padang. Ultisol di daerah ini termasuk sub-order Udult dan sub-kelompok Tropoxult Orthoxic (Yulnafatmawita et al., 2008), dan reaksi tanah masam $(\mathrm{pH}<4,5)$, kejenuhan $\mathrm{Al}$ tinggi dan kejenuhan basa rendah, kapasitas pertukaran kation dan kandungan bahan organik rendah (Alibasyah, 2016). Ultisol juga memiliki permeabilitas lambat hingga sedang, dan stabilitas agregat rendah sehingga sebagian besar tanah ini memiliki kapasitas menahan air rendah dan peka terhadap erosi (Alibasyah, 2016).

Pengasaman tanah adalah proses alami permanen yang ada di sebagian besar tanah yang digunakan untuk produksi tanaman. Jika langkah-langkah yang tepat untuk koreksi keasaman tanah yang berlebihan tidak diterapkan, maka tanah itu akhirnya akan menjadi lebih masam. Dalam meningkatkan kesuburan tanah masam melalui penerapan 
bahan pengapuran yang berbeda adalah praktik yang diakui secara luas untuk meningkatkan produktivitas tanah dan tanaman dengan melakukan 4 ketentuan yaitu dosis yang tepat, cara yang tepat, waktu yang tepat, dan kondisi yang tepat. (Rastija et al., 2014). Namun, pada nilai $\mathrm{pH}$ yang sama tanah yang berbeda memberikan respons yang berbeda terhadap jumlah bahan kapur yang sama dan jenis kapur yang berbeda seperti $\mathrm{CaO}$ (kapur api atau kalsium oksida); $\mathrm{Ca}(\mathrm{OH})_{2}$ (kapur terhidrasi atau kalsium hidroksida); $\mathrm{CaCO}_{3}$ (batu kapur atau kalsit atau kalsium karbonat) dan $\mathrm{CaMg}\left(\mathrm{CO}_{3}\right)_{2}$ (dolomit). Ketersediaan kelarutan dan nutrisi sangat tergantung pada $\mathrm{pH}$ tanah. Salah satu konsekuensi paling jelas dari rendahnya $\mathrm{pH}$ tanah di Limau Manis adalah tingkat fosfor yang tersedia $\left(\mathrm{P}_{2} \mathrm{O}_{5}\right)$ dan sifat kimia lainnya tidak mencukupi. Berdasarkan latar belakang tersebut maka tujuan dari penelitian ini adalah mempelajri perbedaan jenis kapur $[\mathrm{CaO}$; $\mathrm{Ca}(\mathrm{OH})_{2} ; \mathrm{CaCO}_{3}$ dan $\left.\mathrm{CaMg}\left(\mathrm{CO}_{3}\right)_{2}\right]$ pada sifat kimia Ultisols Limau Manis Padang.

\section{Bahan dan Metode}

\section{Waktu dan tempat}

Penelitian ini telah dilakukan di Laboratorium Kimia dan Kesuburan Tanah Fakultas Pertanian, Universitas Andalas, Padang, mulai dari Mei hingga Desember 2018.

\section{Persiapan sampel tanah dan kapur}

Ultisol yang digunakan untuk percobaan ini diambil secara komposit pada kedalaman 0 - 20 $\mathrm{cm}$ dari permukaan tanah di Kebun Percobaan, Fakultas Pertanian, Universitas Andalas, Limau Manis Padang. Kemudian sampel tanah dikeringkan anginkan, dihaluskan lalu diayak dengan ayakan $2 \mathrm{~mm}$ dan diaduk sampai homogen. Kadar air tanah ditentukan, kemudian sampel yang diayak dimasukkan ke dalam pot yang masing-masing setara dengan $500 \mathrm{~g}$ berat kering mutlak. Kapur yang diberikan untuk semua perlakuan dan dicampur dengan tanah. Empat jenis kapur adalah $\mathrm{CaO}$; $\mathrm{Ca}(\mathrm{OH})_{2} ; \mathrm{CaCO}_{3}$ dan $\mathrm{CaMg}\left(\mathrm{CO}_{3}\right)_{2}$. Keempat jenis kapur yang digunakan adalah produk perusahaan swasta di Indonesia, di mana deskripsi masing-masing jenis kapur adalah sebagai berikut: (1) kapur aktif yang digunakan adalah 325 mesh $(0,0017$ inci, $44 \mu \mathrm{m})$ dengan kandungan $\mathrm{CaO} 90 \%$ dan $1 \%$ kandungan air; (2) kapur hidrat pada 325 mesh dengan 95\% $\mathrm{Ca}(\mathrm{OH})_{2}$ konten dan 1\% kadar air; (3) kalsit dalam ukuran 325 mesh dengan kandungan $\mathrm{CaCO}_{3}$ 98.5\% dengan $\mathrm{pH}>9$ unit dan proporsi $2.67 \mathrm{~g} \mathrm{~cm}^{-3}$ dan kadar air $0.1-0.4 \%$ (PT. Niraku Jaya Abadi, 2017) dan (4) Dolomit pada 325 mesh dengan 21\% konten $\mathrm{MgO}$ dan 30\% $\mathrm{CaO}$; dengan $\mathrm{pH}>9,5$ unit dan proporsi $2.66-$ $2.75 \mathrm{~g} \mathrm{~cm}^{-3}$ dan kadar air $0.1-0.5 \%$ (CV. Libra Mandiri Pratama, 2017).

\section{Pelaksanaan penelitian dan analisis tanah}

Penelitian ini menggunakan Rancangan Acak Lengkap dengan 3 ulangan berjumlah 15 unit eksperimen. Formulasi penelitian mengunakan empat jenis kapur sebagai berikut: $\mathrm{K}=$ kontrol; $\mathrm{A}=\mathrm{CaO} ; \mathrm{B}=\mathrm{Ca}(\mathrm{OH})_{2} ; \mathrm{C}=\mathrm{CaCO}_{3} ;$ dan $\mathrm{D}=$ $\mathrm{CaMg}\left(\mathrm{CO}_{3}\right)_{2}$. Penelitian ini mengunakan berbagai jenis kapur dalam proses pengapuran yang ditentukan berdasarkan $\mathrm{Al}$-dd tanah untuk menetralkan potensi racun terhadap tanaman. Jumlah kapur yang diberikan setara dengan 1*Al-dd (1 me Ca $\left.100 \mathrm{~g}^{-1}\right)$ atau sebanyak $\mathrm{CaO}$ sebesar $0,45 \mathrm{~g} \mathrm{pot}^{-1} ; \mathrm{Ca}(\mathrm{OH})_{2}$ kali $0,59 \mathrm{~g}$ pot $^{-1}$; $\mathrm{CaCO}_{3}$ dengan $0,79 \mathrm{~g} /$ pot dan $\mathrm{CaMg}\left(\mathrm{CO}_{3}\right)_{2}$ dengan 1,47 $\mathrm{g} \mathrm{pot}^{-1}$ dengan Al-dd tanah sebesar $3.19 \mathrm{cmol}_{\mathrm{c}} \mathrm{kg}^{-1}$. Kemudian diaduk sampai homogen, kemudian lakukan penyiraman hingga berada pada kapasitas lapangan dan diinkubasi selama 2 minggu. Selanjutnya dilakukan analisis tanah di laboratorium. Analisis tanah sebagai berikut: $\mathrm{pH} \mathrm{H}_{2} \mathrm{O}(1: 1)$ dengan metode Elektrometri, Al dan $\mathrm{H}$-dd dengan metode Volumetric, KTK dan K; Ca; dan $\mathrm{Mg}$-dd dengan metode pencucian $\mathrm{NH}_{4} \mathrm{OAc} 1 \mathrm{~N}$ pH 7 dan diukur menggunakan AAS, P-tersedia dengan metode Bray II, C organik dengan metode Walkley and Black, $\mathrm{N}$ total dengan metode Kjeldahl (Balai Penelitian Tanah, 2012).

\section{Analisis statistik}

Hasil penelitian dilakukan analisis statistik menggunakan Software Statistix 8, dalam menganalisis peningkatan sifat kimia Ultisol dengan berbagai jenis kapur. Data dianalisis secara statistik dengan uji $\mathrm{F}$ analisis varians (ANOVA), jika pengobatan $\mathrm{F}$ dihitung lebih besar dari tabel $\mathrm{F}$ pada tingkat $5 \%$ yang diajukan dan ketika berbeda nyata $\left(^{*}\right) \quad(p$ 


\section{Jurnal Tanah dan Sumberdaya Lahan Vol 7 No 2 : 209-214, 2020}

e-ISSN:2549-9793, doi: 10.21776/ub.jts1.2020.007.2.04

$<0.05)$, sangat nyata $(* *)(\mathrm{p}<0.01)$. Rata-rata dibandingkan dengan menggunakan Uji Lanjut Duncan's New Multiple Range Test (DNMRT).

\section{Hasil dan Pembahasan}

Pada Gambar 1A dapat dilihat bahwa pengaruh perbedaan jenis kapur berpengaruh nyata terhadap $\mathrm{pH}, \mathrm{P}$ tersedia, $\mathrm{Al}$ dan $\mathrm{H}$-dd dengan penambahan kapur sesuai rekomendasi yang diberikan yaitu $1 * 1$ me Ca $100 \mathrm{~g}^{-1}$ pada Ultisol. $\mathrm{pH}$ tanah meningkat dengan penambahan berbagai kapur sementara itu kalium yang dapat dipertukarkan meningkat seiring dengan penambahan berbagai jenis kapur (Gambar 1C) masing - masing sebesar 0.18; 0.24; 0.30; 0.35 unit, dibandingkan dengan kontrol. Waktu yang diperlukan untuk menormalkan $\mathrm{pH}$ tergantung pada berbagai faktor, termasuk jumlah kapur yang ditambahkan dan kapasitas penyangga tanah (Nyberg et al., 2011).

Interpretasi hasil yang ditunjukkan oleh Jasmin dan Heenye (1961) bahwa tanah asam yang berbeda, memiliki kebutuhan kapur dan jumlah kapur yang berbeda sesuai dengan kebutuhan sebagai fungsi dari $\mathrm{pH}$ dan kalsium yang dapat dipertukarkan didalam tanah (Gambar 1C). Peningkatan $\mathrm{pH}$ yang terjadi karena pengapuran memberikan pengaruh nyata pada pengurangan $\mathrm{Al}$ dan $\mathrm{H}$-dd didalam tanah masing - masing sebesar $0.30 ; 0.45 ; 0.76$ dan $0.91 \mathrm{cmol}_{\mathrm{c}} \mathrm{kg}^{-1}$ untuk Al-dd dan 0.00; 0.46; 0.76 dan $0.92 \mathrm{cmol}_{\mathrm{c}} \mathrm{kg}^{-1}$, dibandingkan dengan kontrol. Berdasarkan reaksi kapur didalam tanah akan menghasilkan kalsium $\left(\mathrm{Ca}^{2+}\right)$ dan magnesium $\left(\mathrm{Mg}^{2+}\right)$ khusus dolomit dalam larutan tanah, sehingga menghasilkan kejenuhan basa yang lebih tinggi. Pada saat yang sama, ion aluminium $\left(\mathrm{A} 1^{3+}\right)$ digantikan oleh $\mathrm{Ca}$ dan $\mathrm{Mg}$ dan dinetralkan oleh ion $\mathrm{OH}$. Selanjutnya, $\mathrm{Ca}$ dan $\mathrm{Mg}$ bergabung dengan $\mathrm{HCO}_{3}$ - dan selanjutnya membentuk $\mathrm{Ca}\left(\mathrm{HCO}_{3}\right)_{2}$ dan $\mathrm{Mg}\left(\mathrm{HCO}_{3}\right)_{2}$, yang mengakibatkan $\mathrm{pH}$ tanah masam meningkat (Paradelo et al. 2015).

Penurunan $\mathrm{Al}$ dan $\mathrm{H}$-dd menyebabkan $\mathrm{P}$ tersedia mengalami peningkatan (Gambar 1A) masing-masing sebesar $0.15 ; 0.26 ; 0.67$ dan $1.03 \mathrm{ppm} \mathrm{P}$, dibandingkan dengan kontrol. Peningkatan fosfor yang tersedia ditunjukkan dengan setiap penambahan kapur pertanian dapat dijelaskan dengan pelepasan fosfor organik yang disebabkan oleh peningkatan $\mathrm{pH}$ dan perubahan yang dihasilkan dalam mikroorganisme tanah (Jasmin dan Heenye (1961). Namun fosfat yang diserap secara khusus pada permukaan hidro-oksida, dan dapat diserap ketika $\mathrm{pH}$ dilarutan tanah meningkat (Helyar dan Andersonz (1974) dan memperlihatkan bahwa peningkatan konsentrasi larutan kalsium juga mendukung terjadinya adsorpsi fosfat (Helyar dan Andersonz, 1974), sehingga mengurangi perpindahan fosfat oleh ion hidroksil. Aktivitas disosiasi terjadi pada permukaan fosfat yang diserap bersama dengan kalsium pada permukaan oksida dan liat. Kompleks tersebut dapat melibatkan ion kalsium yang terikat pada dua ion fosfat yang berdekatan dan bermuatan negatif. Efek ini terjadi dalam penambahan kalsit dan dolomit terhadap tanah masam pada tingkat kation dalam ekstrak air (Helyar dan Andersonz, 1974). Peningkatan KTK dengan meningkatnya $\mathrm{pH}$, dan terjadinya netralisasi ion aluminium yang teradsorpsi kuat dan penggantiannya dengan jumlah yang setara dari ion kalsium yang kurang teradsorpsi dengan kuat.

Pengaruh perbedaan jenis kapur dalam aplikasi pengapuran tidak berpengaruh nyata tehadap $\mathrm{C}$ organik, $\mathrm{N}$ total dan rasio $\mathrm{C} / \mathrm{N}$ (Gambar 2B), namun mengalami peningkatan secara rata -rata. Peningkatan C organik dan N total hampir sama untuk setiap jenis kapur yang diberikan masing - masing sebesar 0.12; 0.24; 0.29 dan $0.35 \%$ C dan 0.02; 0.04;0.05 dan $0.05 \% \mathrm{~N}$, dibandingkan dengan kontrol. Menurut Shaban et al. (2015), aplikasi kapur dapat meningkatkan mineralisasi $\mathrm{C}$ dan $\mathrm{N}$ pada tanah masam dan karenanya meningkatkan emisi $\mathrm{N}_{2} \mathrm{O}$. Aplikasi kapur untuk tanah masam di Cina menunjukkan peningkatan konsentrasi $\mathrm{NH}_{4}{ }^{+}$dan $\mathrm{NO}_{3}$, sehingga pelepasan $\mathrm{N}_{2} \mathrm{O}$ ke atmosfer meningkat selama nitrifikasi dan laju denitrifikasi yang lebih tinggi (Shaban et al., 2015). Penerapan kapur melalui manipulasi $\mathrm{pH}$ tanah memainkan peran penting dalam regulasi beberapa proses tanah seperti mineralisasi bahan organik, transformasi N, nitrifikasi, dan denitrifikasi, yang selanjutnya mempengaruhi produksi $\mathrm{N}_{2} \mathrm{O}$ didalam tanah (Shaban et al., 2015). Peningkatan C organik dan $N$ total terhadap aplikasi pengapuran berkaitan erat dengan aktivitas mikroorganisme dalam tanah seperti yang terlihat dari rasio $\mathrm{C} / \mathrm{N}$. 
Jurnal Tanah dan Sumberdaya Lahan Vol 7 No 2 : 209-214, 2020

e-ISSN:2549-9793, doi: 10.21776/ub.jts1.2020.007.2.04

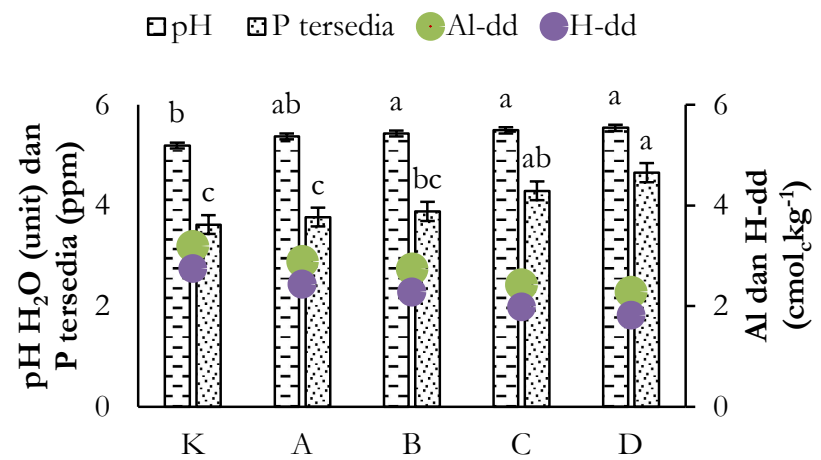

Berbagai Jenis Kapur

$\left[\mathrm{K}=\right.$ Kontrol; $\mathrm{A}=\mathrm{CaO} ; \mathrm{B}=\mathrm{Ca}(\mathrm{OH})_{2} ; \mathrm{C}=\mathrm{CaCO}_{2}$ dan $\left.\mathrm{D}=\mathrm{CaMg}\left(\mathrm{CO}_{3}\right)_{2}\right]$

A

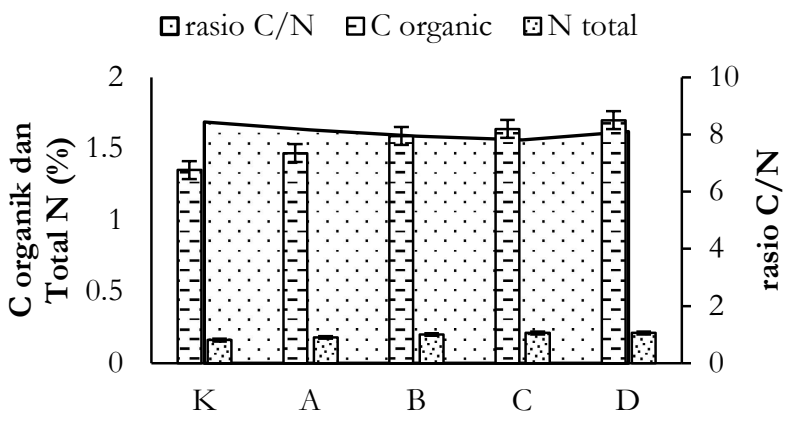

Berbagai Jenis Kapur

$\left[\mathrm{K}=\right.$ Kontrol; $\mathrm{A}=\mathrm{CaO} ; \mathrm{B}=\mathrm{Ca}(\mathrm{OH})_{2} ; \mathrm{C}=\mathrm{CaCO}_{2}$ dan
$\left.\mathrm{D}=\mathrm{CaMg}\left(\mathrm{CO}_{3}\right)_{2}\right]$

$\mathrm{B}$

घKTK $\square$ K-dd $\square$ Ca-dd $\square$ Mg-dd

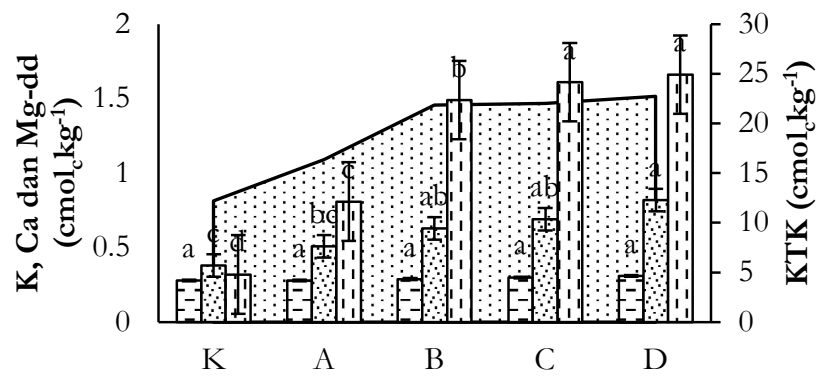

Berbagai Jenis Kapur

$\left[\mathrm{K}=\right.$ Kontrol; $\mathrm{A}=\mathrm{CaO} ; \mathrm{B}=\mathrm{Ca}(\mathrm{OH})_{2} ; \mathrm{C}=\mathrm{CaCO}_{2}$ dan $\mathrm{D}$

$\left.=\mathrm{CaMg}\left(\mathrm{CO}_{3}\right)_{2}\right]$

C

Gambar 1. Pengaruh berbagai jenis kapur terhadap pH, P tersedia, Al dan H-dd (A); C organik, $\mathrm{N}$ total dan rasio C/N (B) dan KTK dan kation basa (C) pada Ultisol. 


\section{Jurnal Tanah dan Sumberdaya Lahan Vol 7 No 2 : 209-214, 2020 e-ISSN:2549-9793, doi: 10.21776/ub.jts1.2020.007.2.04}

Menurut Jasmin dan Heenye (1961), aplikasi kapur memiliki pengaruh yang pasti terhadap dekomposisi tanah melalui sintesis asam humat, peningkatan populasi aktinomiset, peningkatan $\mathrm{pH}$. Peningkatan mineralisasi N setelah proses pengapuran tanah masam telah diakui sejak lama dan dijelaskan secara komprehensif (Wood, 1979). Menurut Khan et al. (2019), emisi kumulatif $\mathrm{N}_{2} \mathrm{O}$ secara substansial meningkat di tanah masam yang diaplikasikan dengan kapur. Berdasarkan sifat tanah yang berbeda-berbeda, populasi mikroba, dan masyarakat yang merespons dengan cara yang berbeda terhadap manipulasi $\mathrm{pH}$ tanah (Page et al., 2010). Menurut Shaaban et al. (2015), aplikasi kalsit dan dolomit secara nyata mengurangi emisi $\mathrm{N}_{2} \mathrm{O}$ dari dua tanah sawah yang bersifat masam. Perubahan $\mathrm{pH}$ tanah yang tinggi pada tanah yang diaplikasikan dengan dolomit meningkatkan aktivitas $\mathrm{N}_{2} \mathrm{O}$-reduktase yang mengubah $\mathrm{N}_{2} \mathrm{O}$ menjadi $\mathrm{N}_{2}$. Mikroorganisme berkembang lebih baik dan mampu mengurangi $\mathrm{N}_{2} \mathrm{O}$ menjadi $\mathrm{N}_{2}$ pada tingkat $\mathrm{pH}$ tinggi (Shaaban et al., 2015).

Pada Gambar. 1C, dapat dilihat bahwa pengaruh perbedaan jenis kapur berpengaruh nyata terhadap KTK dan kation basa Ultisol. Peningkatan KTK akibat proses pengapuran seiring dengan peningkatan $\mathrm{pH}$ tanah (Gambar 1A) dimana peningkatan KTK masing-masing sebesar 4.11; 9.58; 9.81 dan 10.49 cmolc $_{\mathrm{c}} \mathrm{kg}^{-1}$, dibandingkan dengan kontrol. Reaksi kapur dalam menetralkan $\mathrm{H}^{+}$dan melepaskan $\mathrm{Ca}^{2+}$ atau $\mathrm{Mg}^{2+}$ meningkatkan $\mathrm{pH}$ tanah dan KTK yang bergantung pada $\mathrm{pH}$. Ion $\mathrm{Ca}^{2+}$ atau $\mathrm{Mg}^{2+}$ secara stoikiometrik menggantikan $\mathrm{H}^{+}$pada $\mathrm{KTK}$ tergantung $\mathrm{pH}$ yang ada yang besarnya berubah di bawah pengaruh peningkatan alkalinitas. Peningakatan Ca dan Mg yang dapat dipertukarkan setelah proses pengapuran masing-masing sebesar $0.13 ; 0.25 ; 0.31$ dan 0.44 cmolc kg- $^{-1}$ Ca dan $0.49 ; 1.17 ; 1.29$ dan 1.34 $\mathrm{cmol}_{\mathrm{c}} \mathrm{kg}^{-1} \mathrm{Mg}$ dibandingkan dengan kontrol. Menurut Meda et al. (2002) hal lain yang mempengaruhi adalah selektivitas yang lebih tinggi dari situs negatif koloid untuk $\mathrm{Ca}$ daripada untuk Mg. Batu kapur dan kapur dolomit meningkatkan $\mathrm{pH}, \mathrm{Ca}, \mathrm{Mg}$, dan $\mathrm{CO}_{3}$ (Meda et al., 2002).

Pada Gambar 1C terlihat pengaruh berbagai jenis kapur dapat meningkatkan K-dd sebesar $0.00 ; 0.01 ; 0.02$ dan $0.03 \mathrm{cmol}_{\mathrm{c}} \mathrm{kg}^{-1}$, dibandingkan dengan control. Ketika garam kalium ditambahkan ke tanah, konsentrasi $\mathrm{K}$ dalam larutan tanah meningkat dengan cepat dan sebagian kecil secara bertahap dapat berpindah ke lokasi pertukaran kation (Viadé et al., 2011). Ion $K$ yang mengalami perubahan dapat kembali ke formula yang tersedia dalam jangka panjang. Pengapuran tidak secara langsung mempengaruhi $\mathrm{K}$ yang dapat dipertukarkan (Viadé et al., 2011). Namun, pengapuran memiliki pengaruh positif terhadap peningkatkan K-dd (Das dan Saha, 2014). Pengendapan ion aluminium dan besi yang dapat dipertukarkan sebagai polimer hidroksialuminium dan hidroksi-besi yang bertindak sebagai penyangga antara lapisan silikat, sehingga menghambat pelepasan lapisan untuk ion $\mathrm{K}$, maka dapat meningkatkan selektivitas ion K itu sendiri (Das dan Saha, 2014). Pengapuran dapat meningkatkan $\mathrm{K}$ yang dapat ditukar dalam tanah karena pengendapan polimer hidroksil aluminium dan besi hidroksil yang menghalangi pelepasan $\mathrm{K}$ yang dapat ditukar dan pengapuran juga menyebabkan perluasan dan pelapukan kisi mineral tanah liat di tanah yang memfasilitasi pelepasan kisi ion K (Das dan Saha, 2014). Aplikasi batu kapur dan dolomit pada tanah meningkatkan stabilitas agregat tanah melalui pembuatan jembatan $\mathrm{Ca}$ dan $\mathrm{Mg}$ dengan karbon organik tanah dan partikel liat terhadap sifat fisik (Shaaban et al., 2015). Peningkatan agregasi tanah setelah aplikasi dolomit menciptakan lebih banyak kondisi aerobik untuk difusi oksigen yang lebih baik ke dalam tanah, menghasilkan pengurangan emisi $\mathrm{N}_{2} \mathrm{O}$ (Shaaban et al., 2015).

\section{Kesimpulan}

Pengapuran menggunakan dolomit $\left[\mathrm{CaMg}\left(\mathrm{CO}_{3}\right)_{2}\right]$ lebih efektif dalam memperbaiki sifat kimia Ultisol, dibandingkan dengan jenis kapur lainnya $\left[\mathrm{CaO}, \mathrm{Ca}(\mathrm{OH})_{2}\right.$, atau $\left.\mathrm{CaCO}_{3}\right]$. Pengaruh dolomit terhadap $1 * \mathrm{Al}$-dd $(1 \mathrm{me} \mathrm{Ca}$ $\left.100 \mathrm{~g}^{-1}\right)$ dapat meningkatkan sifat kimia Ultisol dari Limau Manis Padang, dibandingkan dengan kontrol.

\section{Ucapan Terima Kasih}

Penulis berterima kasih kepada DIPA Universitas Andalas melalui Fakultas Pertanian yang telah 


\section{Jurnal Tanah dan Sumberdaya Lahan Vol 7 No 2 : 209-214, 2020}

e-ISSN:2549-9793, doi: 10.21776/ub.jts1.2020.007.2.04

menyediakan dana untuk melakukan Penelitian Terapan pada tahun 2017.

\section{Daftar Pustaka}

Alibasyah, M.R. 2016. Perubahan beberapa sifat fisika dan kimia ultisol akibat pemberian pupuk kompos dan kapur dolomit pada lahan berteras. Jurnal Floratek 11(1): 75-87.

Balai Penelitian Tanah. 2012. Analisis Kimia Tanah, Air, Tanaman dan Pupuk. Balai Penelitian Tanah. Bogor. 246 hal.

Das, R. and Saha, D. 2014. Effect of liming on the changes of different forms of potassium in an acid soil treated with $\mathrm{N}$ and $\mathrm{K}$ fertilizers. Journal of the Indian Chemical Society 91(9): 16191625.

Helyar, K.R. and Anderson, A.J. 1974. Effects of calcium carbonate on the availability of nutrients in an acid soil. Soil Science Society of America Journal 38(2): 341-346.

Jasmin, J.J. and Heeney, H.B. 1961. The effect of lime on the status of nitrogen, phosphorus, potassium, calcium and magnesium in a few vegetables grown on acid peat soils. Canadian Journal of Plant Science 42: 445-451.

Khan. S.A., Khan, S.U., Qayyum, A., Gurmani, A.R., Khan, A., Khan, S.M., Ahmed, W, Mehmood, A. and Amin, B.A.Z. 2019. Integration of humic acid with nitrogen wields an auxiliary impact on physiological traits, growth and yield of maize (Zea mays L.) varieties. Applied Ecology and Environmental Research 17(3): 6783-6799.

Meda, A.R., Pavan, M.A., Cassiolato, M.E. and Miyazawa, M. 2020. Dolomite lime's reaction applied on the surface of a sandy soil of the Northwest Paraná, Brazil. Brazilian Archives of Biology and Technology 45(2): 219-222, doi : 10.1590/S1516-89132002000200014.

Nyberg, K.A., Vinnerås, B., Lewerin, S.S., Kjellberg, E. and Albihn, A. 2011. Treatment with $\mathrm{Ca}(\mathrm{OH})_{2}$ for Inactivation of Salmonella typhimurium and Enterococcus faecalis in soil contaminated with infected horse manure. Journal of Applied Microbiology 110(6): 15151523, doi : 10.1111/j.1365-2672.2011.05006.x.
Page, R.M., Gutsmiedl, A., Fukumori, A., Winkler, E., Haass, C. and Steiner, H. 2010. B-amyloid precursor protein mutants respond to $\Gamma$ secretase modulators. Journal of Biological Chemistry 285(23): 17798-17810, doi : 10.1074/jbc.M110.103283.

Paradelo, R., Virto, I. and Chenu, C. 2015. Net effect of liming on soil organic carbon stocks: a review. Agriculture, Ecosystems and Environment 202: 98-107, doi : 10.1016/j.agee.2015.01.005.

Rastija, D., Zebec, V. and Rastija, M. 2014. Sensitivity of planetary boundary layer height to crop type and fertilization level in an anticyclonic weather. 13th Alps-Adria Scientific Workshop-Villach, Ossiacher See, Austria. 63: 267-270. doi 10.12666/Novenyterm.63.2014.Suppl.

Shaaban, M., Peng, Q., Hu, R., Wu, Y., Lin, S. and Zhao, J. 2015. Dolomite application to acidic soils: a promising option for mitigating $\mathrm{N}_{2} \mathrm{O}$ emissions. Environmental Science and Pollution Research 22(24): 19961-19970, doi : 10.1007/s11356-015-5238-4.

Viadé, A., Fernández-Marcos, M.L., HernándezNistal, J. and Alvarez, E. 2011. Effect of particle size of limestone on $\mathrm{Ca}, \mathrm{Mg}$ and $\mathrm{K}$ contents in soil and in sward plants. Scientia Agricola 68(2): 200-208. doi : 10.1590/s010390162011000200010

Wood, B.R.A. 1979. The Effect of Lime on Release and Plant Uptake of Nitrogen From Soils of The Natal Midlands. Proceedings of The South African Sugar Technologists' Association, (June). 173-176.

Yulnafatmaawita, Adrinal, dan Daulay, A.F. 2008. Pengaruh pemberian beberapa jenis bahan organik terhadap stabilitas agregat tanah Ultisol Limau Manis. Jurnal Solum V(1): 7-13. 